\section{References}

1. Alsoufi B, Rao V, Borger MA, Maganti M, Armstrong S, Feindel CM, et al. Shortand long-term results of triple valve surgery in the modern era. Ann Thorac Surg. 2006;81:2172-8.

2. Cohn LH, Adams DH, Couper GS, Bichell DP, Rosborough DM, Sears SP, et al. Minimally invasive cardiac valve surgery improves patient satisfaction while reducing costs of cardiac valve replacement and repair. Ann Surg. 1997; 226:421-8.

3. Gammie JS, Zhao Y, Peterson ED, O'Brien SM, Rankin JS, Griffith BPJ Less-invasive mitral valve operations: trends and outcomes from the Society of Thoracic Surgeons Adult Cardiac Surgery Database. Ann Thorac Surg. 2010;90: 1401-8.

\title{
Novel technique for delayed sternal closure: Soft tissue approximation with substernal bridge
}

\author{
Cha Rajakaruna, MD, ${ }^{a}$ Gladys M. Rodriguez, BS, ${ }^{a}$ Bijoy G. Rajbanshi, MD, \\ Bulat A. Ziganshin, MD, ${ }^{\text {a,b }}$ and John A. Elefteriades, MD, ${ }^{a}$ New Haven, Conn, and Kazan, Russia
}

Delayed sternal closure (DSC) is used when the approximation of the hemisterna after cardiac surgery leads to embarrassment of hemodynamics due to poor cardiac function of a dilated heart or reperfusion myocardial edema after prolonged ischemic time. ${ }^{1,2}$ DSC also can be used when the chest is packed and left open for uncontrolled hemorrhage or when continued access is required for central mechanical circulatory support. DSC often is a measure of last resort when all other maneuvers have failed. DSC is used more frequently in the pediatric population, but it can represent a lifesaving maneuver in the adult population.

Most of the techniques described for DSC involve suturing the skin with a membrane with or without a stent holding the sternal edges apart and then covering the chest with an adhesive airtight dressing. ${ }^{3,4}$

We describe a technique that over many years has been used safely in our practice and offers substantial advantages over other techniques described in the literature. The technique reported has the advantage of complete soft tissue closure, maintaining complete internal mediastinal sterility. In addition, the pericardial bridge protects the heart from the sharp sternal edges. This closure can be permanent if the overall situation so requires. This

\footnotetext{
From the Aortic Institute at Yale-New Haven Hospital, ${ }^{a}$ Yale University School of Medicine, New Haven, Conn; and Department of Surgical Diseases \#2, ${ }^{\text {b }}$ Kazan State Medical University, Kazan, Russia.

Disclosures: John Elefteriades reports consulting fees from Cryolife, Covidien, and Datascope, and equity ownership in Coolspine. The other authors have nothing to disclose with regard to commercial support.

Received for publication July 21, 2014; revisions received Aug 25, 2014; accepted for publication Aug 31, 2014; available ahead of print Oct 1, 2014.

Address for reprints: John A. Elefteriades, MD, Aortic Institute at Yale-New Haven Hospital, Yale University School of Medicine, 789 Howard Ave, Clinic Bldg CB317, New Haven, CT 06510 (E-mail: john.elefteriades@yale.edu).

J Thorac Cardiovasc Surg 2014;148:2427-9

$0022-5223 / \$ 36.00$

Copyright (c) 2014 by The American Association for Thoracic Surgery

http://dx.doi.org/10.1016/j.jtcvs.2014.08.048
}

review was covered by an approved institutional review board protocol.

\section{SURGICAL TECHNIQUE}

We start by placing a pericardial bridge between the nonapproximated sternal halves to prevent heart laceration against the sharp sternal edges (Figure 1). For this purpose, we use a large $(8 \times 14 \mathrm{~cm})$ bovine pericardial patch (Synovis Surgical Innovation, St Paul, Minn), which is sutured underneath each sternal edge with 3 to 5 interrupted mattress sutures (0 Ticron $75 \mathrm{~cm}$ on GS27 needle; Covidien, Mansfield, Mass; 88863190-61). The patch is laid on the heart, and sutures are passed from cardiac side to skin side in a mattress fashion along the length of the pericardial patch. The needles are brought out through the corresponding points of each hemi-sternum and tied on the upper surface of the bone, so that the patch lines the underside of the sternal edges and bridges the gap as shown in Figure 1. Chest tubes are left below the patch.

Next, the muscle and soft tissues overlying the sternum are approximated fully in our usual 3-layer closure ( 0 Vicryl to muscle and rectus fascia, 2-0 Vicryl to the subcutaneous tissues, and 3-0 monofilament suture to skin) reinforced by skin staples (Figure 2). We see little or no hemodynamic embarrassment from approximation of the soft tissues. We can always bring these soft tissues together adequately without lateral mobilization. This soft tissue closure provides 3 complete, watertight layers isolating the mediastinum from the exterior.

Standard wound dressings are applied until the patient is ready for definitive closure when clinically appropriate (usually within a few days of the original operation). Definitive closure is done by reopening, removing the pericardial membrane, approximating the bone with wires, and closing the soft tissues in 3 layers. 


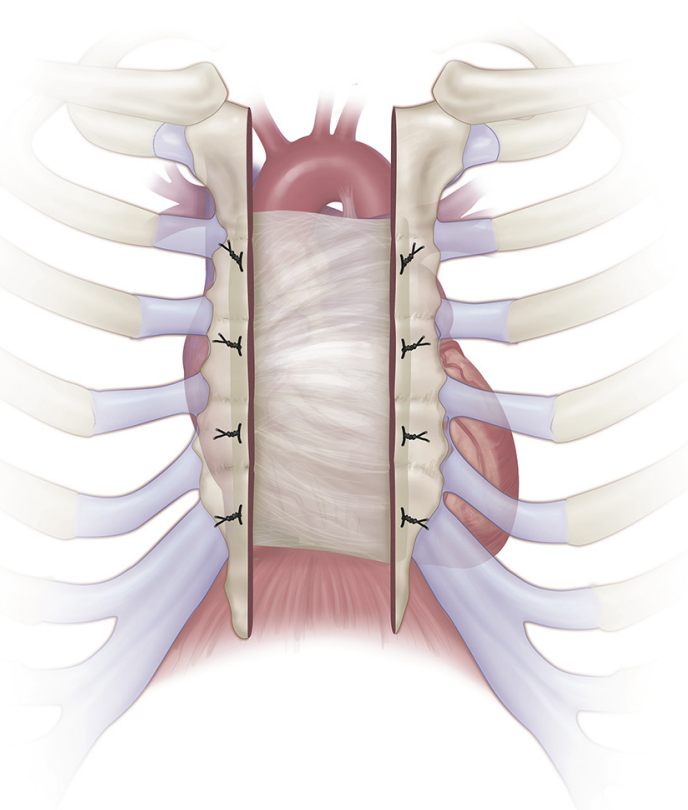

FIGURE 1. Placement of pericardial bridge between the nonapproximated sternal halves.

\section{CLINICAL SUMMARY}

Between 2005 and 2013 (8 years), we applied this technique in 16 patients (Table 1). In all patients, chest closure was not possible because of hemodynamic

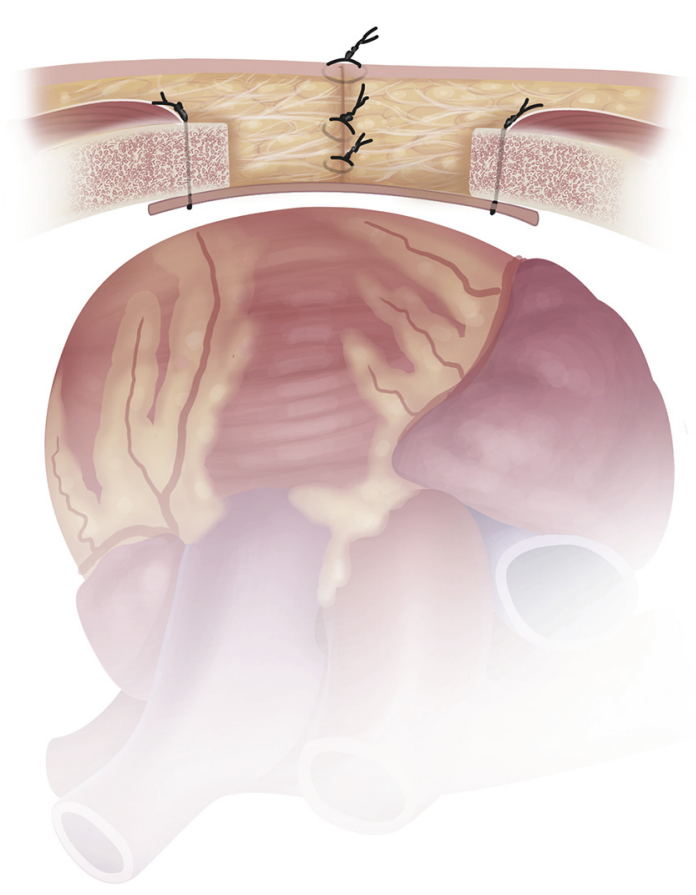

FIGURE 2. Full approximation of muscle and soft tissues overlying the sternum.
TABLE 1. Clinical data with pericardial bridge technique over 8 years

\begin{tabular}{lc}
\hline \multicolumn{1}{c}{ Clinical variables } & Values (\%) \\
\hline $\mathrm{n}$ & 16 \\
Female & $11(68.8)$ \\
Age (y) & $69(53-80)$ \\
Surgery type & \\
$\quad$ Low EF CABG & $2(12.5)$ \\
AVR & $1(6.3)$ \\
AVR + CABG & $3(18.8)$ \\
Complex aortic + DHCA & $5(31.3)$ \\
Redo AVR for false aneurysm & $2(12.5)$ \\
Redo complex aortic for false aneurysm & $2(12.5)$ \\
Cardiac transplant & $1(6.3)$ \\
Deaths & $2(12.5)$ \\
Open sternum at primary operation & $12(75.0)$ \\
$\quad$ (remaining left open after reexploration) & \\
Definitive closure & $12(75.0)$ \\
Time to closure, d (range) & $2(1-10)$ \\
Infections & $2(12.5)$ \\
Deep infection & $1(6.3)$ \\
\hline$A V R$, Aortic valve replacement; $C A B G$, coronary artery bypass grafting; $D H C A$, deep \\
hypothermic circulatory arrest; $E F$, ejection fraction.
\end{tabular}

embarrassment on approximation of the hemi-sterna. Among these 16 patients, there were 2 hospital deaths (both redo false aneurysm repairs) due to the underlying cardiac condition. Of the 14 survivors, 12 had a definitive delayed chest closure with sternal wires. We accepted the pericardial bridge as a permanent solution in 2 patients who were extubated and recovered without need for bone approximation. The remaining patients were maintained on mechanical ventilation and turned in bed without any consequence until later formal sternotomy closure. Most patients were ready for an early definitive closure (mean, 2 days; range, 1-10 days) because of a quick hemodynamic recovery. Deep sternal infection developed in 1 patient, which was resolved with antibiotic treatment.

\section{DISCUSSION}

DSC can be an effective strategy to overcome hemodynamic instability related to adverse effects of primary sternal approximation in hearts that are enlarged because of poor function or reperfusion edema after prolonged ischemic arrest. However, DSC is an independent predictor for deep mediastinal infection and mortality. ${ }^{5,6}$

Our technique is simple and effective. In our experience we have always been able to close the soft tissues in the standard fashion, thus creating a biological seal, which we postulate is more effective against surgical site infections.

The pericardial barrier protects the swollen myocardium from the edges of the sternum and allows the patient to be turned as necessary for pressure area management. It is our experience that the patient can be extubated without sternal closure if rapid progress is made clinically, and in 
very selected occasions we have accepted this as a permanent closure.

With this technique, we also found that when the patient is returned to the operating room for definitive closure, the sternum has gradually approximated itself over time. In fact, the edges are usually found only 1 to $2 \mathrm{~cm}$ apart, permitting easy, well-tolerated wire fixation.

We believe that this closure technique is appropriate for the majority of patients who need to have the sternum remain open for hemodynamic reasons. Membrane closure may be better (quicker) for a severely unstable patient or a (very thin) patient without adequate soft tissues for approximation across the longer transverse distance necessitated by the open sternum.

\section{CONCLUSIONS}

We recommend this technique, which can be lifesaving, for its 2-fold advantages for the rare patient with precarious postbypass hemodynamics: (1) avoiding the hemodynamic consequences of sternal approximation, while (2) providing a complete, natural "seal" of native body tissues.

\section{References}

1. Boeken U, Assmann A, Mehdiani A, Akhyari P, Lichtenberg A. Open chest management after cardiac operations: outcome and timing of delayed sternal closure. Eur J Cardiothorac Surg. 2011;40:1146-50.

2. Misawa Y. Indication for delayed sternal closure. J Thorac Cardiovasc Surg. 1997 114:874.

3. Satoh H, Sakai K, Koyama M, Matsuda H. Spool-like stent for the open sternum after cardiac operations. Ann Thorac Surg. 1997;63:572-4.

4. Haenen L, Rodrigus IE, Boeckxstaens CJ, Amsel BJ, Moulijn AC. Sternal stent for delayed closure. Ann Thorac Surg. 1997;64:1519-20.

5. Das S, Rubio A, Simsic JM, Kirshbom PM, Kogon B, Kanter KR, et al. Bloodstream infections increased after delayed sternal closure: cause or coincidence. Ann Thorac Surg. 2011:91:793-7.

6. Harder EE, Gaies MG, Yu S, Donohue JE, Hanauer DA, Goldberg CS, et al Risk factors for surgical site infection in pediatric cardiac surgery patients undergoing delayed sternal closure. J Thorac Cardiovasc Surg. 2013; 146: 326-33. 